\title{
Review
}

\section{A Review on Life Cycle Assessment of the Olive Oil Production}

\author{
Mattia Rapa ${ }^{1, *(\mathbb{C} \text { and Salvatore Ciano }}{ }^{2}$ \\ 1 Department of Management, Sapienza University of Rome, 00161 Rome, Italy \\ 2 Department of Chemical and Physical Health Risks, Sciensano, 1050 Ixelles, Belgium; \\ Salvatore.ciano@sciensano.be \\ * Correspondence: mattia.rapa@uniroma1.it
}

check for

updates

Citation: Rapa, M.; Ciano, S. A

Review on Life Cycle Assessment of the Olive Oil Production.

Sustainability 2022, 14, 654. https://

doi.org/10.3390/su14020654

Academic Editor: Michael Blanke

Received: 14 December 2021

Accepted: 5 January 2022

Published: 7 January 2022

Publisher's Note: MDPI stays neutral with regard to jurisdictional claims in published maps and institutional affiliations.

Copyright: (c) 2022 by the authors. Licensee MDPI, Basel, Switzerland. This article is an open access article distributed under the terms and conditions of the Creative Commons Attribution (CC BY) license (https:// creativecommons.org/licenses/by/ $4.0 /)$.

\begin{abstract}
Olive oil is one of the most globally recognized high-value products, with 4 million hectares cultivated in the Mediterranean area. The production process involves many stages: farming, extraction, packing, and waste treatment. Each one of these stages should present critical points for the environmental impacts, and for this reason, the entire sector is adopting mitigation strategies to begin to be more sustainable. The mitigation actions' efficiency should be evaluated through environmental indicators or environmental impact assessment by Life Cycle Assessment (LCA). This review aimed to carry out an overview of recent papers (2011-2021) involving an LCA study in the olive oil supply chain by giving a framework of what is included in LCA studies and highlighting the main contributors to environmental impacts. The main scholarly literature databases have been exploited, highlighting a great increase in publications, especially from the producer countries. The review results reflect the heterogeneity of the production process. However, the use of pesticides, fertilizers, water, and fuel for machinery heavily weigh on the farming stage's environmental impact. Finally, special focus was given to key elements of LCA studies in the olive oil supply chain, such as functional unit, system boundaries, impact categories, calculation method, and software widely used.
\end{abstract}

Keywords: olive oil; Life Cycle Assessment (LCA); sustainability; environmental assessment; supply chain

\section{Introduction}

Nowadays, the effects of climate change are concrete. Rising sea levels, the increasing temperature of the Earth, and biodiversity losses are some of the effects of global warming. Mitigation actions for climate change are a direct call to avoid the continuous increase of global warming. These programs are addressed across all sectors (primary, secondary, and tertiary) [1-4].

According to recent data, the agri-food segment was the second most impacting sector, with $18.4 \%$ of total greenhouse gas emissions. Many contributions concur with the total environmental impact within the agri-food sector. The supply chain accounts for $18 \%$ of the total emission, including retail, packaging, transport, and food processing operations. Livestock and fisheries provide up to $31 \%$ of total emissions (e.g., manure management, fuel use from fisheries), crop production for animal feed and human food $27 \%$, and land use $24 \%$ [5-11]. In this framework, the agricultural sector is evolving to increase the efficiency in the use of natural resources. Organic production, vegetable alternatives to meat, and local and seasonal production are just some examples of the actions implemented to have resilient and sustainable food production [12-15].

The efficiency of mitigation actions needs to be evaluated through tools such as environmental indicators or environmental impact assessment [14].

Life Cycle Assessment (LCA) is the most used tool to perform an environmental impact assessment in the agri-food sector and across all sectors [16,17]. 
Defined by ISO 14040 and ISO 14044, LCA is acknowledged worldwide as the "golden standard" to execute an environmental sustainability evaluation, driving the choices of producers, consumers, and decision-makers [18-21].

This review aimed to carry out an overview of recent papers (2011-2021) involving an LCA study in the olive oil supply chain, excluding partial LCA studies (e.g., those including only carbon balance or energy demand).

Olive oil is one of the most globally recognized high-value agriculture products. Europe is the top olive oil producer, with $67 \%$ of total production and 4 million hectares cultivated. Spain, Italy, and Greece have been confirmed for years as the leading producers of olive oil [22-24].

The supply chain of olive oil involves many stages, such as farming (including cultivation and harvesting), extraction of oil from olive, packing, and waste treatment steps [25,26].

Each one of these stages could present critical points for environmental impact. For example, the use of machinery or the manual work in harvesting should give different impact scenarios [27], as well as the disposal or re-use of wastes [28]. In this regard, the application of LCA is a useful tool to identify the most impacting steps and compare them with other more sustainable ones [29-32].

In this context, this review aimed to give a framework of what is included in the LCA studies for each stage of the olive oil supply chain. The main contributors to environmental impacts were also highlighted.

Some studies provided a total assessment of the olive oil supply chain, involving all the production stages or excluding only one. On the other hand, many papers focused only on one stage, providing environmental assessment and comparative assessment of the step examined.

Critical literature analysis in this context is not a novelty [29]. However, a constant update is essential due to the value of olive oil production and to the knowledge of its environmental impacts.

In addition, this review also aimed to map and compare the key elements of LCA studies in the olive oil supply chain. Functional units, system boundaries, impact categories, impact assessment methods, and the software most used were assessed in order to find possible common areas and to harmonize guidelines for future studies.

\section{Methodology}

The review was based on available papers from international literature involving only "full" LCA studies focused on the olive oil supply chain. Partial LCA studies, e.g., including only carbon balance or energy demand, were not considered. The literature review was performed by consulting Web of Science, Science Direct, Scopus, and Google Scholar. The keywords used for the research were "Life Cycle Assessment" or "LCA" coupled with "olive oil."

About 80 references were observed, of which 78 were published from 2011 to 2021. Analyzing the papers revealed that only 28 papers performed a "full" LCA on olive oil production, including all the stages of the supply chain or only one.

LCA needs to be performed following the four steps indicated in the ISOs: goal and scope definition, life cycle inventory, life cycle impact assessment, and results interpretation [33].

In the first phase, the goal of the LCA is declared, indicating the intended application, the reasons for the study, and the expected audience. In addition, the scope should be defined in this phase, ensuring compatibility with the stated goal. The scope step includes the system to be studied with its boundaries, the functional unit to which all the calculations are referred, the method and the impact categories used, data requirements, allocation procedures, limitations, and assumptions used.

The second stage is the life cycle inventory analysis, which involves data collection and quantification of the system's inputs and outputs studied. 
The third step, the core process of the LCA, is the life cycle impact assessment. This stage aims to evaluate the potential environmental impact of the data from the life cycle inventory analysis. The use of environmental impact categories and indicators is usually possible by specific software. This process could be iterative, reviewing or modifying the goal and the scope of the assessment. The impact calculation can be performed by using many different methods and, therefore, impact categories. These processes make it challenging to compare different studies, even similar ones. At the same time, the comparison is crucial to highlight the improvement in the life cycle or hot spots of the process $[20,34]$.

The LCA studies were evaluated in-depth, considering eight core characteristics:

- Goal and scope;

- Supply chain location;

- Functional unit;

- System boundaries;

- Comparison;

- Calculation method;

- Software.

In terms of time, an increasing trend of the number of papers on olive oil LCA published per year was observed (Figure 1), starting from 2011. A pause in growth was recorded in the three years 2018-2020, probably due to the focus of research on remedies against Xylella infestations.

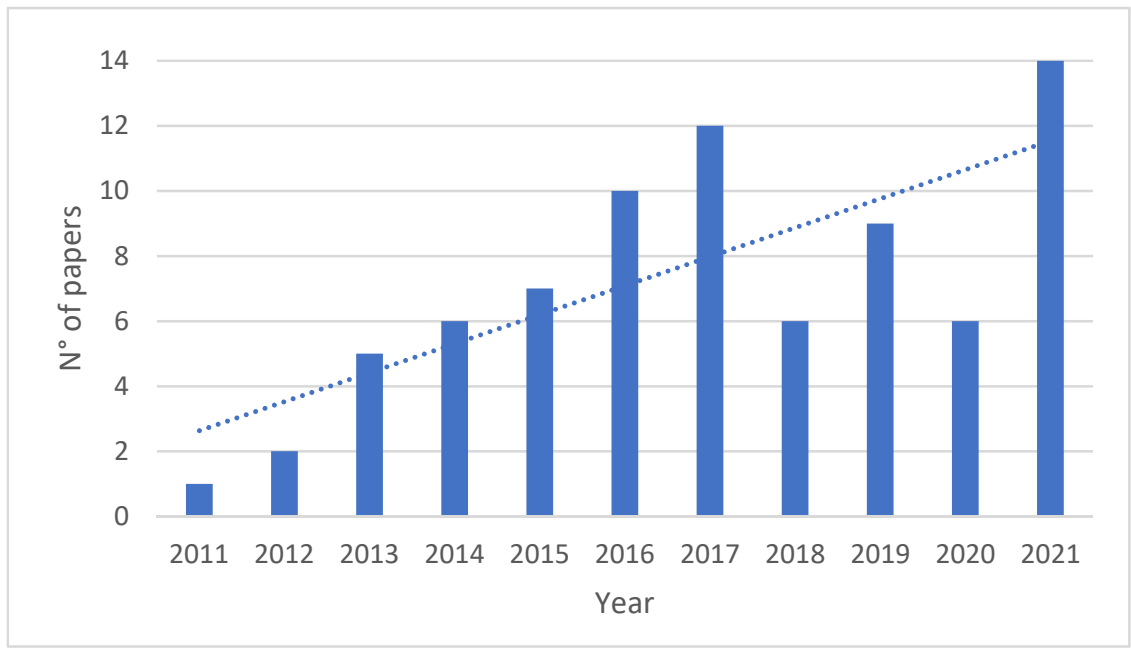

Figure 1. Papers published per year with "LCA" and "olive oil" keywords. Dotted line: trendline.

Nevertheless, in 2021 the growing trend started again.

The provenience of the authors of the selected paper was also analyzed. It was possible to point out that the authors' nationality matched with the geographical areas with higher olive oil production, as shown in Figure 2. This evidence underlines the strong connection between the production processes and research interest. These two sectors affect each other, and they cooperate to valorize and preserve typical local production. 


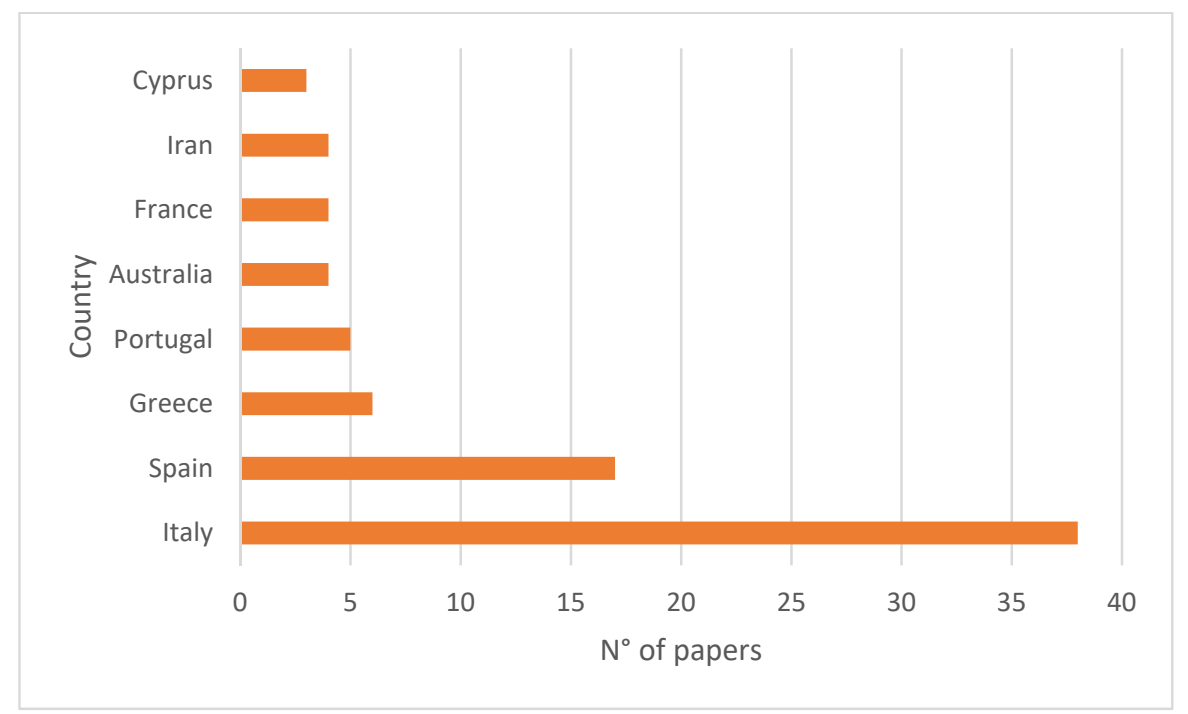

Figure 2. Country distribution of papers with "LCA" and "olive oil" keywords (years covered 2011-2021)

\section{Olive Oil Production Process}

This section provides a short overview of the olive oil production processes to understand the subsequent LCA application better.

The olive oil production process consists of different and distinct phases (Figure 3). The first stage is olive cultivation, which represents the raw material provisioning. Each year 19 million tons of olives are produced, but the production is not instantaneous. Indeed, the plant must grow from four to eight years to provide an acceptable production [35]. The olives begin to appear towards the end of May, and they arrive at their full ripening in September. In this period the harvesting phase occurs, which can be manual, mechanized, or mechanical. This depends on whether the olives are harvested by hand (manual harvesting), with the help of tools that facilitate harvesting (mechanized harvesting), or by employing machines that the operators only drive (mechanical harvesting). The harvesting phase is crucial because the final oil quality is directly linked to olive quality. Premature or late harvesting and prolonged or incorrect storage are aspects that negatively influence olive oil quality parameters [36].

After harvesting, preliminary operations prepare the olives for subsequent processing, such as defoliation and washing. Afterward, the olives go through the pressing process. The pressing system must be chosen according to the type of olives and, above all, the type of product to be obtained. With this phase begins the actual extraction process. The pressing can be done using a traditional muller, or it can take place using a hammer or disc crushers. The resulting paste could consist exclusively of the olive pulp or include the stone. The type of pressing is therefore critical. An energetic machine breaks the stone and leads to the loss of these substances, which are a source of well-being and improve the product's organoleptic properties. The pressing phase is followed by the so-called malaxing phase, in which the olive paste is mixed to favor the coalescence of the oil droplets into larger drops, which can then be more easily separated with the next phase. It is essential to keep all the fundamental parameters under control, such as time, temperature, and the amount of oxygen the paste comes into contact with [37]. These parameters affect the enzymatic activity responsible for the final presence in the oil of minor and volatile components, which are also the most interesting ones. Kneading for a long time and at high temperatures would give a higher extraction yield despite a low-quality profile. For this reason, producers try to keep the olive paste in the malaxers for as little time as possible and at a temperature never higher than $30^{\circ} \mathrm{C}$. The oil extraction is carried out by separating the liquid phase (must oil) from the solid one (pomace). Different types of machines can be used depending on the separation principle used [38]. The oil extraction from the paste 
can be carried out by pressure, using a hydraulic press, or by centrifugation, using threeor two-phase centrifuges. Extraction that involves the use of the hydraulic press is also defined as the "traditional method" and represents an evolution of the systems used in previous centuries. The liquid component obtained with the expensive extraction systems is crude oil and consists of oil, a small fraction of vegetation water, and solid particles and mucilage in suspension. The solid parts are separated with a sieve, through which the crude oil is passed. Then the oil is separated with a plate centrifuge. After the extraction, the oil must be bottled. Bottling is one of the most delicate stages of the processing process because it is necessary to reduce contact with air during the transfer. Olive oil containers must be made of material that avoids contact with light as much as possible, as light can be a cause of degradation. As an alternative to the widely used dark glass, tinplate containers, previously treated with antioxidant materials, may be used. Another critical factor during the bottling phase is the overall time of the operation. In fact, it must be quick in order to preserve the organoleptic properties of freshly pressed olives [39].

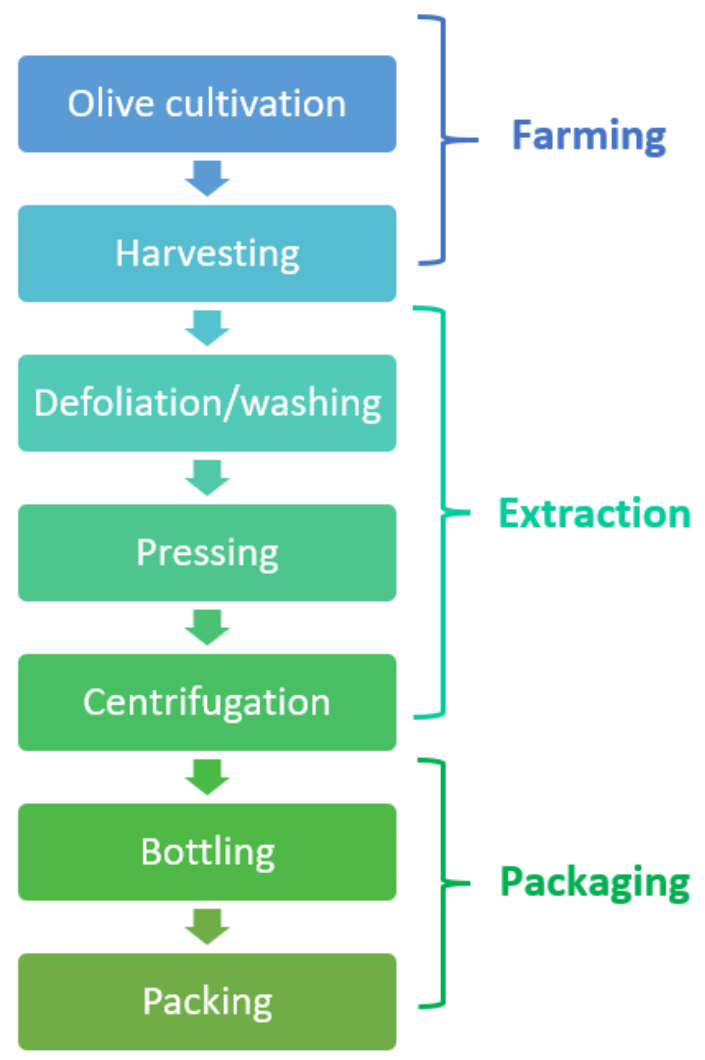

Figure 3. Flow chart of the olive oil production process.

Olive oil production has an average yield of $15-18 \%$, and wastes represent the remaining percentage. Olive pomace (35-45\%) and olive mill wastewater (38-48\%) are the main by-products of this process. Disposal of olive oil wastes is one of the factors with the most significant impact for the producing companies due to their pollutant properties [40].

\section{LCA Application in Olive Oil Supply Chain}

The Life Cycle Assessment evaluating impact is associated with all the supply chain stages, from raw material extraction to waste treatment. This review focused on LCA studies in the olive oil supply chain by evaluating farming, extraction, packaging, and waste treatment stages. All the papers analyzed in this review have favored the primary data in their studies for data collection. The secondary data used were obtained from the Ecoinvent [41], Agri-footprint [42], and ELCD [43] databases. The material inputs and outputs involved in each stage are reported in Table 1. 
Table 1. Input and output used in LCA studies on the olive oil supply chain.

\begin{tabular}{ccc}
\hline STAGES & INPUT & OUTPUT \\
\hline Farming & Electricity, water, fertilizers, pesticides, fuel, lubricants, machinery & Olive, wastes \\
\hline Production & Electricity, water & Oil, wastes \\
\hline Packaging & $\begin{array}{c}\text { Polyethylene terephthalate, polyethylene, aluminum polyurethane, } \\
\text { polylactic acid, glass, electricity, machinery }\end{array}$ & Bottles, wastes \\
\hline Waste & $\begin{array}{r}\text { Water, fertilizers, pesticides, anhydrous ammonia, phosphoric acid, } \\
\text { nitrogen gas, manure, fuel, electricity, machinery }\end{array}$ & $\begin{array}{c}\text { Oil, olive pomace, olive mill wastewater, } \\
\text { wastes }\end{array}$ \\
\hline
\end{tabular}

The functional units most used were olive ( $1 \mathrm{~kg}$ to 1 ton) or olive oil ( $1 \mathrm{~L}$ to 1 bottle) amounts. The impact assessment methods most used in the impact assessment were ILCD, ReCiPe, and CML. No preference emerged in using one of these methods over another (Figure 4). It was pointed out that a significant proportion of the authors $(25 \%)$ did not report the name of the software used. SimaPro was confirmed as the most used paid software $(68 \%)$, and even OpenLCA was shown to be a helpful tool for LCA studies (Figure 5).

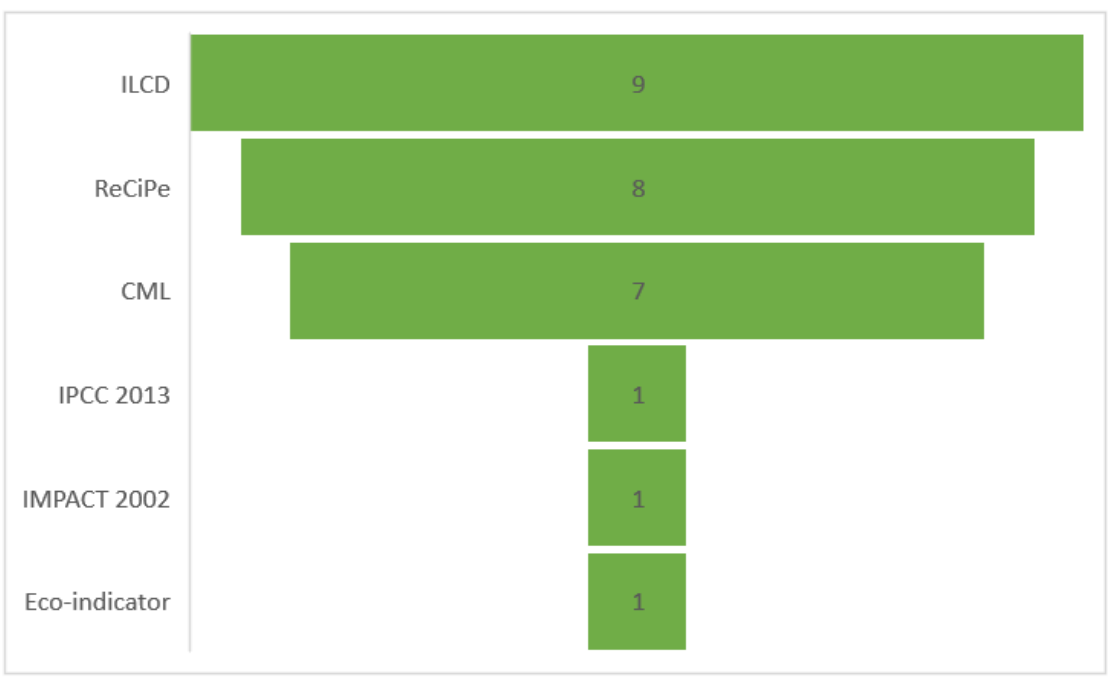

Figure 4. Impact assessment methods used in the papers evaluated.

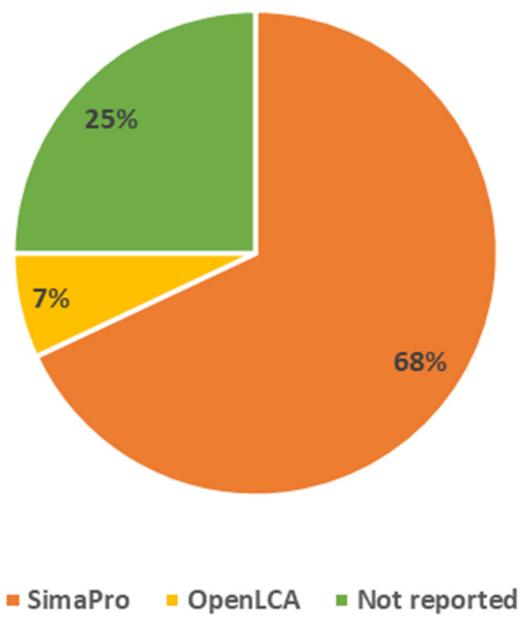

Figure 5. Software used in the papers evaluated. 


\subsection{Farming Stage}

The primary raw material for oil production is olives. So, it should be possible to include all the operations necessary to obtain olives in the farming stage as the raw material procurement. Two main areas were evaluated in this stage: soil management and intensive production (Table 2). Romero-Gàmez et al. (2017) and Ben Abdallah et al. (2021) compared conventional and organic practices [44,45]. Organic systems highlighted lower environmental impacts in almost all the categories studied. The minor impact was due to the absence of synthetic fertilizers and pesticides. Romero-Gàmez et al. highlighted that the fertilizer stage accounted for $81-87 \%$ of climate change and acidification impact categories [44]. Similar results were obtained by Ben Abdallah et al., who reported a $4 \%$ reduction in climate change impact by using an organic system and even a $40 \%$ decrease in the acidification category [45]. The same papers also studied the different impacts of irrigation and rainfed systems. Both papers highlighted that irrigation led to less environmental impact, from 10 to $34 \%$ of reduction in the freshwater eutrophication and freshwater ecotoxicity impact categories. Despite water and electricity being involved in the irrigated systems, the highest productivity led to lower impact [44,45]. The last factor analyzed in soil management was the use of mechanized systems. All the references examining this argument agreed that it was impossible to indicate a unique interpretation of results. Romero-Gàmez et al. obtained a 15-36\% decrease in all the impact categories using less mechanized systems. However, Bernardi et al. (2018) and Bernardi et al. (2021) pointed out that the results were highly influenced by the chosen functional unit $[27,46]$. Considering the $\mathrm{kg}$ of olives as a functional unit, the highly mechanized systems had higher impacts in the sum of the resource, ecosystem, and human health impact categories $(6.1 \mathrm{Pt}$ vs. $0.5-3.2 \mathrm{Pt}$ ). Nevertheless, when the cultivation hectares were used as a functional unit, the mechanized system was less impacting or comparable $(14.5 \mathrm{Pt})$ to the other systems $(12.5-36.0 \mathrm{Pt})$. These findings are related to the high productivity achieved by using mechanized systems [26,45,47].

The second area evaluated was the use of intensive and super-intensive systems for olive cultivation. Even in this case, identifying the sustainable choice was not uniform. De Gennaro et al. (2012) found lower impacts for the intensive systems than the superintensive ones [47]. The slightest reduction $(-21 \%)$ was obtained in the abiotic depletion category and the biggest reduction in the terrestrial, freshwater, and marine eutrophication categories $(-37 \%)$. However, other studies pointed out that less impact should be reached by increasing the intensity of a system $[44,45]$. As mentioned earlier, the functional units defined in the goal and scope definition step have a major influence on the LCA results.

\subsection{Extraction Stage}

Extraction is the core step in olive oil production. Pressing, kneading, and centrifugation turn olives into oil. The new technologies or improvement of existing plants represent an approach to innovate the olive oil extraction process. The studies of De Luca et al. (2018) and Stillitano et al. (2019) focused on this stage. Table 3 shows the main characteristics of the LCAs, and the secondary data were obtained from the Ecoinvent and Agri-footprint databases. De Luca et al. proposed adding coadjutant during the process. This addition led to the best environmental performance for almost all the impact categories analyzed. Indeed, an average decrease of $12 \%$ was reached in all the categories.

For example, global warming went from $0.178 \mathrm{~kg} \mathrm{CO}_{2}$ eq./ $\mathrm{L}$ to $0.158 \mathrm{~kg} \mathrm{CO}_{2}$ eq./L, whereas the water consumption went from $0.769 \mathrm{~m}^{3} / \mathrm{L}$ to $0.682 \mathrm{~m}^{3} / \mathrm{L}$. The lesser impact was related to the $33.5 \%$ shorter processing and better efficiency of machinery used. The only exception was for the mineral resource scarcity category, which registered an increment of $31 \%$ due to using calcium carbonate. Nevertheless, this implementation negatively influenced the quality parameters of the olive oil, such as reducing antioxidant species [48]. On the other hand, Stillitano et al. found an innovative mill plant whose olive oil has high quality parameters [49]. The olive oil produced with the innovative plant had better performance in terms of the peroxide value $(-43 \%)$ and total polyphenol $(+15 \%)$ and total 
tocopherol $(+21 \%)$ content. From an environmental point of view, this plant had worse impact in all the categories considered (around 5\% more impact) compared to a traditional one. This plant used low-oxygen pressure milling with higher energy demand, responsible for the worse environmental effects. This finding makes it possible to point out that there is a non-unique efficient implementation in the extraction step, and each case should be considered separately. Focusing on the desired product, the goal is to find the right balance between product quality and sustainability.

\subsection{Packaging Stage}

Packaging turns goods into a commodity, and it supports commodity commercialization. Two papers, one by Accorsi et al. in 2015 and another by Giovenzana et al. in 2019, described the material sustainability involved in the packaging stage (Table 4). In the olive oil supply chain, many materials are usually involved in packaging. The most used is glass. Glass bottles are ideal containers, especially amber ones, because they maintain unaltered olive oil quality. Glass, however, is highly fragile and has a high specific weight. These factors highly affect transport due to both safety and environmental impact. The study by Accorsi et al. assessed the environmental impacts of alternative packaging solutions to glass bottles [50]. Specifically, polyethylene terephthalate (PET) and recycled PET (R-PET) bottles were compared with traditional glass ones. It was highlighted that the glass bottles were $40 \%$ less impacting than the PET ones. These findings were related to the high recyclability of glass. R-PET, indeed, showed the lowest impact in the global warming category. At the same time, it is important to appreciate that the functional unit chosen also influenced these findings. Indeed, $1 \mathrm{~kg}$ of glass enables the production of two final bottles $(0.46 \mathrm{~kg} / \mathrm{bottle})$, whereas $1 \mathrm{~kg}$ of PET or R-PET generates 28 bottles $(0.036 \mathrm{~kg} / \mathrm{bottle})$. Therefore, the impact reduction is also related to the high efficiency of plastic bottles and their low specific weight, positively influencing transport.

It is widely recognized that plastic materials negatively affect the environment, due to their raw material (petroleum) and especially to their high impact on end-of-life. Giovenzana et al. (2019) evaluated the substitution of plastic single-portion packaging with a bio-plastic one [51]. They replaced polyethylene and polyethylene terephthalate with polylactic acid and bio-polyethylene. Their findings pointed out that the expected improvement of environmental sustainability of bio-plastic packaging was not confirmed for all the impact categories. In fact, the bio-plastic packaging was more impacting than traditional ones in the freshwater ecotoxicity $(+78 \%)$, land use $(+35 \%)$, and water resource depletion categories $(+14.6 \%)$. The increment of impact in these categories was related to the activities necessary along the production chain, such as maize cultivation, starch production, and other farming activities. Giovenzana et al. also studied the waste scenario, highlighting that the innovative packaging is more environmentally sustainable, especially in climate change and human cancer toxicity impact categories.

\subsection{Waste Treatment Stage}

The disposal of wastes is one of the main problems in the olive oil production industry in terms of the environmental impact and economic cost [52]. Many papers performed an LCA on energy and matter recovery (Table 5). Olive pomace valorization was explored by Parascanu et al. in 2018, De Marco et al. in 2017, Puig-Gamero et al. in 2021, and Erses Yay et al. in 2021 [53-56]. Parascanu et al. assessed the olive pomace pyrolysis process. The highest impact values were found for the climate change category (3390 tons of $\mathrm{CO}_{2}$ eq.), findings associated with the utilities consumption (air, water, electricity) [53]. Therefore, the energy recovery by this process appeared not very sustainable. Indeed, De Marco et al. evaluated the impacts of using olive pomace to produce pomace oil (used in the food industry) and exhausted pomace (used as biofuel). They found that increasing olive pomace processing showed an increment in the values of all the environmental impact categories (e.g., global warming potential $+43 \%$, ozone layer depletion $+26 \%$ ) [54]. An interesting paper, published by Puig-Gamero et al., analyzed the use of olive pomace as 
raw material for methanol production compared to natural gas [55]. In this case, the new strategy also had higher levels for all the impact categories studied, especially in the ozone layer depletion $(+91 \%)$, marine eutrophication $(+91 \%)$, and water consumption potential $(+95 \%)$ categories. These findings were probably due to the low methanol efficiency of this production. Erses Yay et al. compared the hydrothermal carbonization of olive pomace with its incineration [56]. This approach allowed less impact than incarceration on the energy recovery potential. It is noteworthy that all the impact categories for hydrothermal carbonization had negative values. Batuecas et al. studied the anaerobic digestion of olive pomace and olive mill wastewater as alternatives to soil disposal [28]. The anaerobic digestion for biogas production revealed a reduction in the environmental impacts in all the categories considered (from $41 \%$ to $61 \%$ ). The common practice of spreading olive oil wastes on soil was pointed out as an environmental hazard due to modification of the chemical properties of soil and the contamination of the aquifers.

Regarding matter recovery from olive oil production wastes, Hijaila et al. (2013) studied its use for activated carbon production [57], El Hanandeh (2015) studied its use for briquette and pellet manufacturing [58], Espadas-Aldana et al. (2021) studied its use as filler for polymeric composites [59], and Lòpez-Garcì et al. (2021) studied its incorporation into ceramic bricks [60]. Despite all the studies pointing out that the recovery of the waste resulted in a sustainable approach, its incorporation into ceramic bricks led to different results. Indeed, the ceramic bricks without olive pomace had a global warming potential value of $0.263 \mathrm{~kg} \mathrm{CO}_{2}$ eq. In contrast, the one made with $10 \%$ olive pomace had a value of $0.424 \mathrm{~kg} \mathrm{CO}_{2}$ eq. Therefore, the environmental benefits of this practice were minimal.

\subsection{General Studies}

In addition to the studies focused only on one stage of olive oil production, papers including all or almost all the stages were found (Table 6). El Hanandeh et al. (2016) evaluated all the steps included in this review, such as farming, extraction, packaging, and wastes. Tsarouhas et al. (2015) and Guarino et al. (2019) reported all the stages except for waste, whereas Salomone et al. (2012) and Arzoumanidis et al. (2017) excluded the packaging step. Salomone et al. (2012), Iraldo et al. (2014), and Fernàndez-Lobato (2021) reported only on the farming and extraction stages.

All the studies highlighted that the farming stage is the most impacting due to the use of fertilizers and pesticides [61-66]. Fernandez-Lobato et al. also pointed out that impacts in the climate change or global warming potential categories were dependent on each year's olive production [64]. They also calculated the carbon sequestration, with an average of $45.4 \pm 1.5 \%$. The $\mathrm{CO}_{2}$ balance during the years 2015-2020 showed no significant variability, so the year with the highest climate change value $(2017 / 2018)$ was also the year with the highest carbon sequestration $(46.36 \%)$. The carbon balance was also studied by Fernandez-Lobato et al. [67]. They highlighted that the on-farm procedures had a greater $\mathrm{CO}_{2}$ catch (53-54\%) than the off-farm ones (46-47\%). Tsarouhas et al. and Guarino et al. demonstrated that, after farming, another impacting stage is the packaging one $[65,66]$. Tsarouhas et al. found a high value in the photochemical oxidation $\left(0.079 \mathrm{~g} \mathrm{C}_{2} \mathrm{H}_{6}\right)$, climate change (243.57 $\mathrm{g} \mathrm{CO}_{2}$ eq.), and energy consumption (3.70 MJ) impact categories. High energy consumption was also founded by Guarino et al. They pointed out that bottle production covered $80 \%$ of all energy used in the transformation phase. A special mention must be made of the study by Arzoumanidis et al., who mapped the possibility of having a simplified LCA tool in the agri-food industry [68]. They compared several LCA tools for four agri-food industry products, including olive oil, highlighting that using a simplified approach should be suitable for this sector and may eliminate misunderstanding resulting from different studies. 
Table 2. Key elements of LCA studies on the farming stage.

\begin{tabular}{|c|c|c|c|c|c|c|c|c|}
\hline Goal and Scope & Place & Functional Unit & System Boundaries & Comparison & Method & Software & Impact Categories & Refs. \\
\hline $\begin{array}{c}\text { Harvesting } \\
\text { machines }\end{array}$ & Italy & $\begin{array}{l}1 \mathrm{~h} \text { of harvesting, } \\
1 \mathrm{~kg} \text { of harvested } \\
\text { product }\end{array}$ & $\begin{array}{l}\text { Modular approach, only } \\
\text { harvesting }\end{array}$ & Different harvesting machines & ReCiPe 2008 & SimaPro 8.1 & $\begin{array}{l}\text { GWP, OD, TAC, FE, ME, HT, POF, } \\
\text { PMF, TEC, FEC, MEC, IR, ALU, } \\
\text { ULU, NLT, WD, MD, FD }\end{array}$ & {$[27]$} \\
\hline $\begin{array}{l}\text { Optimization of } \\
\text { olive growing } \\
\text { practices }\end{array}$ & Spain & 1 ton of olives & $\begin{array}{l}\text { Irrigation, soil management, } \\
\text { pruning, fertilizers, } \\
\text { pesticides, harvesting }\end{array}$ & $\begin{array}{l}\text { Traditional systems, intensive } \\
\text { systems, super-intensive } \\
\text { system }\end{array}$ & $\begin{array}{l}\text { ILCD } 2011 \\
\text { Midpoint }\end{array}$ & SimaPro 8.0 & GWP, AC, FE, FEC, LU, WRD & {$[44]$} \\
\hline $\begin{array}{l}\text { Environmental } \\
\text { sustainability in } \\
\text { olive growing }\end{array}$ & Tunis: & $\begin{array}{l}1 \text { ton of } \\
\text { olives and } 1 \text { ha of } \\
\text { cultivated } \\
\text { olive-growing area }\end{array}$ & $\begin{array}{l}\text { Soil } \\
\text { management, fertilizers, } \\
\text { pesticides, pruning, } \\
\text { harvesting }\end{array}$ & $\begin{array}{l}\text { Traditional systems, intensive } \\
\text { systems, super-intensive } \\
\text { system }\end{array}$ & $\begin{array}{l}\text { ILCD } 2011 \\
\text { Midpoint }\end{array}$ & SimaPro 8.5 & GWP, AC, FE, FEC & [45] \\
\hline $\begin{array}{l}\text { Harvesting } \\
\text { mechanization }\end{array}$ & Italy & $\begin{array}{c}1 \mathrm{~h} \text { of harvesting, } \\
1 \text { hectare of } \\
\text { harvested area, } \\
1 \mathrm{~kg} \text { of harvested } \\
\text { product }\end{array}$ & $\begin{array}{l}\text { Modular approach, only } \\
\text { harvesting }\end{array}$ & $\begin{array}{l}\text { Mechanized scenarios, } \\
\text { mechanical-aided harvesting, } \\
\text { fully manual harvesting }\end{array}$ & ReCiPe 2008 & SimaPro 8.5 & $\begin{array}{l}\text { GWP, OD, TAC, FE, ME, HT, POF, } \\
\text { PMF, TEC, FEC, MEC, IR, ALU, } \\
\text { ULU, NLT, WD, MD, FD }\end{array}$ & [46] \\
\hline $\begin{array}{c}\text { Innovative } \\
\text { olive-growing } \\
\text { models }\end{array}$ & Italy & 1 ton of olives & $\begin{array}{l}\text { Cultivation phase, growing } \\
\text { phase, plant removal, } \\
\text { disposal }\end{array}$ & $\begin{array}{l}\text { High-density orchard vs } \\
\text { super-high-density orchard }\end{array}$ & $\begin{array}{l}\text { CML } \\
2000\end{array}$ & - & $\begin{array}{c}\text { AD, AC, GWP, OD, HT, FEC, MEC, } \\
\text { TEC, POF }\end{array}$ & [47] \\
\hline Goal and Scope & Place & Functional Unit & System Boundaries & Comparison & Method & Software & Impact Categories & Refs. \\
\hline $\begin{array}{l}\text { EVOO Processing } \\
\text { Innovations }\end{array}$ & Italy & $\begin{array}{c}1 \\
\text { bottle containing } \\
0.75 \mathrm{~L} \text { of EVOO }\end{array}$ & $\begin{array}{l}\text { From cradle to the milling } \\
\text { plant gate (excluding } \\
\text { distribution, selling use) }\end{array}$ & $\begin{array}{l}\text { Introduction of a physical } \\
\text { co-adjuvant (calcium carbonate) } \\
\text { vs. without co-adjuvant }\end{array}$ & ReCiPe 2016 & SimaPro 8.4 & $\begin{array}{l}\text { GWP, OD, IR, OF, PMF, TAC, FE, } \\
\text { ME, TEC, FEC, MEC, HT, LU, MRS, } \\
\text { FRS, WC }\end{array}$ & [48] \\
\hline
\end{tabular}


Table 3. Cont.

\begin{tabular}{|c|c|c|c|c|c|c|c|c|}
\hline Goal and Scope & Place & Functional Unit & System Boundaries & Comparison & Method & Software & Impact Categories & Refs. \\
\hline $\begin{array}{c}\text { Innovative } \\
\text { technologies in } \\
\text { EVOO extraction }\end{array}$ & Italy & $1 \mathrm{~L}$ of EVOO & $\begin{array}{l}\text { Gate to gate of oil mill plant } \\
\quad \text { (olive oil extraction) }\end{array}$ & $\begin{array}{c}\text { Innovative plant vs. traditional } \\
\text { one }\end{array}$ & ILCD 2011 & SimaPro 8.5 & $\begin{array}{l}\text { GWP, OD, HT, PMF, POF, AC, TE, } \\
\text { FE, ME, FET, LU, WRD, MRD }\end{array}$ & [49] \\
\hline
\end{tabular}

$\mathrm{AC}=$ acidification, $\mathrm{FE}=$ freshwater eutrophication, $\mathrm{FEC}=$ freshwater ecotoxicity, $\mathrm{FSR}=$ fossil resource scarcity, GWP $=$ global warming potential, $\mathrm{HT}=$ human toxicity, $\mathrm{IR}=$ ionizing radiation, $\mathrm{LU}=$ land use, $\mathrm{LU}=$ land use, $\mathrm{ME}=$ marine eutrophication, $\mathrm{MEC}=$ marine ecotoxicity, MRD = mineral resource depletion, $\mathrm{MRS}=$ mineral resource scarcity, $\mathrm{OD}=$ ozone depletion, $\mathrm{OF}=$ ozone formation, $\mathrm{PMF}=$ particulate matter formation, $\mathrm{POF}=$ photochemical oxidant formation, $\mathrm{TAC}=$ terrestrial acidification, $\mathrm{TE}=$ terrestrial eutrophication, $\mathrm{TEC}=$ terrestrial ecotoxicity, $\mathrm{WC}=$ water consumption, $\mathrm{WRD}=$ water resource depletion.

Table 4. Key elements of LCA studies on the packaging stage.

\begin{tabular}{|c|c|c|c|c|c|c|c|c|}
\hline Goal and Scope & Place & Functional Unit & System Boundaries & Comparison & Method & Software & Impact Categories & Refs. \\
\hline $\begin{array}{c}\text { Extra-virgin olive } \\
\text { oil (EVOO) } \\
\text { bottles }\end{array}$ & Italy & $1 \mathrm{~L}$ bottle of EVOO & $\begin{array}{l}\text { Supply from the production } \\
\text { areas, consolidation of } \\
\text { EVOO } \\
\text { at the bottling facility, } \\
\text { supply of packaging and } \\
\text { auxiliary material, bottling } \\
\text { and processing, storage and } \\
\text { distribution processes, EOL } \\
\text { treatments }\end{array}$ & Plastic bottle vs. glass bottle & - & SimaPro 7.1 & GWP, OD, POF, AC, EU, NRF & [50] \\
\hline $\begin{array}{l}\text { Packaging } \\
\text { for olive oil }\end{array}$ & Italy & $\begin{array}{c}\text { Single-use } \\
\text { packaging (olive } \\
\text { oil content equal } \\
\text { to } 10 \mathrm{~mL}\end{array}$ & $\begin{array}{l}\text { Raw material extraction, } \\
\text { transformation and } \\
\text { production phases, } \\
\text { disposal of the used } \\
\text { packaging }\end{array}$ & $\begin{array}{c}\text { Traditional packaging } \\
\text { (polyethylene, aluminum, } \\
\text { polyethylene terephthalate) vs. } \\
\text { innovative packaging } \\
\text { (polylactic acid, } \\
\text { bio-polyethylene) }\end{array}$ & ILCD 2011 & SimaPro 8.5 & $\begin{array}{c}\text { GWP, HTnc, HTc, FEC LU, WD, } \\
\text { MRD }\end{array}$ & [51] \\
\hline
\end{tabular}

$\mathrm{AC}=$ acidification, EU = eutrophication, FEC = freshwater ecotoxicity, GWP = global warming potential, HT = human toxicity, LU = land use $\mathrm{MRD}=$ mineral resource depletion, $\mathrm{NRF}=$ non-renewable fossil, $\mathrm{OD}=$ ozone depletion, $\mathrm{POF}=$ photochemical oxidant formation, $\mathrm{WD}=\mathrm{water}$ depletion. 
Table 5. Key elements of LCA studies on the waste stage.

\begin{tabular}{|c|c|c|c|c|c|c|c|c|}
\hline Goal and Scope & Place & Functional Unit & System Boundaries & Comparison & Method & Software & Impact Categories & Refs. \\
\hline $\begin{array}{l}\text { Waste disposal from olive oil } \\
\text { production }\end{array}$ & Italy & $\begin{array}{l}1 \mathrm{~L} \text { of olive oil } \\
\text { production }\end{array}$ & $\begin{array}{l}\text { Cultivation, oil production, end-of-life of } \\
\text { olive oil production waste }\end{array}$ & $\begin{array}{c}\text { Anaerobic } \\
\text { digestion and conventional } \\
\text { disposal on soil }\end{array}$ & ILCD & Simapro 8.5.2 & GWP, AC, TE, WRD, CED & [28] \\
\hline $\begin{array}{l}\text { Olive pomace valorization } \\
\text { through pyrolysis }\end{array}$ & Spain & $100 \mathrm{~kg}$ olive pomace & $\begin{array}{l}\text { Olive production, olive } \\
\text { oil extraction, and pyrolysis of olive pomace }\end{array}$ & $\begin{array}{l}\text { Conventional vs. ecological } \\
\text { crop }\end{array}$ & $\begin{array}{l}\text { ReCiPe } \\
\text { Midpoint; } \\
\text { ReCiPe } \\
\text { Endpoint }\end{array}$ & SimaPro 8.2 & $\begin{array}{l}\text { GWP, OD, TA, FE, MA, HT, } \\
\text { POF, PMF, TET, FET, MET, } \\
\text { ALO, WD, FD }\end{array}$ & [53] \\
\hline $\begin{array}{l}\text { Olive pomace } \\
\text { processing }\end{array}$ & Italy & $\begin{array}{c}1 \mathrm{~kg} \text { of pomace oil and } \\
1 \mathrm{~kg} \text { of } \\
\text { exhausted pomace }\end{array}$ & $\begin{array}{l}\text { Industrial stages (gate-to-gate } \\
\text { approach) }\end{array}$ & $\begin{array}{l}\text { Varying the type of olive } \\
\text { pomace }\end{array}$ & $\begin{array}{l}\text { IMPACT 2002+ } \\
\text { Midpoint }\end{array}$ & - & $\begin{array}{c}\text { C, NC, RI, IR, OD, RO, AET, } \\
\text { TET, TA, LO, AAC, AE, } \\
\text { NRE, ME }\end{array}$ & [54] \\
\hline Methanol from olive pomace & Spain & $1 \mathrm{~kg}$ of methanol & Cradle-to-gate approach & $\begin{array}{l}\text { Methanol } \\
\text { production from natural gas } \\
\text { vs. methanol from olive } \\
\text { pomace }\end{array}$ & $\begin{array}{l}\text { ReCiPe } 2016 \\
\text { Midpoint }\end{array}$ & SimaPro 9 & $\begin{array}{l}\text { GWP, OD, POF, TA, FE, ME, } \\
\text { HT, FFP, WC }\end{array}$ & [55] \\
\hline $\begin{array}{l}\text { Hydrothermal carbonization of } \\
\text { olive pomace }\end{array}$ & Turkey & 1 ton of olive pomace & $\begin{array}{l}\text { Energy recovery of hydrochar, } \\
\text { anaerobic digestion of wastewater from } \\
\text { HTC, and energy recovery of } \\
\text { biogas }\end{array}$ & Incineration & CML-IA & SimaPro 9.0 & $\begin{array}{l}\text { AD, GWP, OD, HT, FET, } \\
\text { MET, TE, PO, AC, EU }\end{array}$ & [56] \\
\hline $\begin{array}{l}\text { Activated carbon (AC) production } \\
\text { process from olive-waste cakes }\end{array}$ & Tunisia & $1 \mathrm{~kg}$ of $\mathrm{AC}$ & $\begin{array}{l}\text { Transporting, drying raw material, crushing, } \\
\text { impregnating, pyrolysis, cooling; washing, } \\
\text { filtering, drying the washed AC, crushing } \\
\text { the final AC }\end{array}$ & Stages of AC production & $\begin{array}{l}\text { CML } 2 \text { Baseline } \\
2000\end{array}$ & Simapro 7.3 & $\begin{array}{l}\text { AD, AP, EU, GWP, OD, HT, } \\
\text { FET, TET, PO, CED }\end{array}$ & [57] \\
\hline $\begin{array}{l}\text { Management alternatives for } \\
\text { waste generated from the } \\
\text { olive oil industry }\end{array}$ & Australia & $\begin{array}{l}1 \mathrm{mg} \text { of olive solid } \\
\text { waste at the mill }\end{array}$ & $\begin{array}{c}\text { Briquette manufacturing and use, } \\
\text { pellet manufacturing and use, } \\
\text { Pyrolysis in mobile units, and use of bio-oil } \\
\text { and char as energy } \\
\text { substitutes }\end{array}$ & - & $\begin{array}{l}\text { ReCiPe } \\
\text { Midpoint; } \\
\text { CML } 2001\end{array}$ & OpenLCA & $\begin{array}{l}\text { GWP, OD, EP, AP, FDP, HT, } \\
\text { IR, POF }\end{array}$ & [58] \\
\hline $\begin{array}{l}\text { Ceramic brick manufacturing } \\
\text { process incorporating olive } \\
\text { pomace }\end{array}$ & Spain & $1 \mathrm{~kg}$ of brick & Cradle to gate & $\begin{array}{l}\text { Traditional brick vs. brick with } \\
\text { olive pomace }\end{array}$ & $\begin{array}{l}\text { IPCC, CML } 2 \\
\text { Baseline } 2000\end{array}$ & SimaPro 8.3 & $\begin{array}{l}\mathrm{AD}, \mathrm{AC}, \mathrm{GWP}, \mathrm{OD}, \mathrm{HT}, \mathrm{FET}, \\
\text { MET, TE, POF }\end{array}$ & [60] \\
\hline
\end{tabular}

$\mathrm{AAC}=$ aquatic acidification, $\mathrm{AC}=$ acidification, $\mathrm{AD}=$ abiotic depletion, $\mathrm{AE}=$ aquatic eutrophication, $\mathrm{AET}=$ aquatic ecotoxicity, $\mathrm{ALO}=$ agricultural land occupation, $\mathrm{AP}=$ acidification potential, $\mathrm{C}=$ carcinogens, $\mathrm{CED}=$ cumulative energy demand, $\mathrm{EP}=$ eutrophication potential, $\mathrm{EU}=$ eutrophication, FD = fossil depletion, FDP = fossil fuel depletion, FE = freshwater eutrophication, FET = freshwater ecotoxicity, FFP = fossil fuel potential, FRS = fossil resource scarcity, GWP = global warming potential, $\mathrm{HT}=$ human toxicity, $\mathrm{IR}=$ ionizing radiation, $\mathrm{LO}=$ land occupation, $\mathrm{LU}=$ land use, $\mathrm{MA}=$ marine eutrophication, $\mathrm{ME}=$ mineral extraction, $\mathrm{MET}=$ marine ecotoxicity, $\mathrm{MRS}=$ mineral resource scarcity, $\mathrm{NC}=$ non-carcinogens, $\mathrm{NRE}=$ non-renewable energy, $\mathrm{OD}=$ ozone depletion, $\mathrm{OF}=$ ozone formation, $\mathrm{PMF}=$ particulate matter formation, $\mathrm{POF}=$ photochemical oxidant formation, $\mathrm{RI}=$ respiratory inorganics, $\mathrm{RO}=$ respiratory organics, $\mathrm{TA}=$ terrestrial acidification, $\mathrm{TE}=$ terrestrial eutrophication, $\mathrm{TET}=$ terrestrial ecotoxicity, $\mathrm{WC}$ = water consumption, $\mathrm{WD}=$ water depletion, $\mathrm{WRD}=$ water resource depletion. 
Table 6. Key elements of LCA studies on different olive oil chain stages.

\begin{tabular}{|c|c|c|c|c|c|c|c|c|c|c|}
\hline \multirow{2}{*}{ Place } & \multirow{2}{*}{$\begin{array}{l}\text { Functional } \\
\text { Unit }\end{array}$} & \multicolumn{4}{|c|}{ System Boundaries } & \multirow{2}{*}{ Compared To } & \multirow{2}{*}{ Method } & \multirow{2}{*}{ Software } & \multirow{2}{*}{ Impact Categories } & \multirow{2}{*}{ Refs. } \\
\hline & & Farming & Production & Packaging & Waste & & & & & \\
\hline Italy & $1 \mathrm{~kg}$ of EVOO & $X$ & $X$ & & & $\begin{array}{l}\text { Different stages of } \\
\text { olive oil chain }\end{array}$ & CML 2000 & SimaPro 7.3 & $\begin{array}{c}\mathrm{AD}, \mathrm{AC}, \mathrm{EU}, \mathrm{GWP}, \mathrm{OD}, \mathrm{HT}, \\
\mathrm{FEC}, \mathrm{MEC}, \mathrm{TEC}, \mathrm{POF}, \mathrm{WD}, \\
\text { NRE }\end{array}$ & [61] \\
\hline Jordan & $\begin{array}{l}1 \mathrm{~kg} \text { of packed } \\
\text { olive oil }\end{array}$ & $x$ & $x$ & $x$ & $x$ & $\begin{array}{l}\text { Small-scale farmers } \\
\text { vs. micro-scale } \\
\text { farmers }\end{array}$ & $\begin{array}{l}\text { ReCiPe Midpoint } \\
2013\end{array}$ & $\begin{array}{l}\text { openLCA } \\
\text { v1.4.1 }\end{array}$ & AC, PMF, HT, GWP, ALO & [63] \\
\hline Spain & $\begin{array}{c}1 \mathrm{~kg} \text { of } \\
\text { unpacked } \\
\text { virgin olive oil }\end{array}$ & $X$ & $X$ & & $X$ & $\begin{array}{l}\text { Farming vs. } \\
\text { processing }\end{array}$ & ILCD Midpoint 2011 & SimaPro 9.0 & $\begin{array}{l}\text { GWP, OD, HT, PM, IR, POF, } \\
\text { AC, TE, FE, ME, FEC, LU, } \\
\text { WRD, MFRD }\end{array}$ & [64] \\
\hline Greece & $\begin{array}{c}1 \text { bottle of } 1 \mathrm{~L} \\
\text { of EVOO }\end{array}$ & $x$ & $X$ & $x$ & & $\begin{array}{l}\text { Different stages of } \\
\text { olive oil chain }\end{array}$ & Eco-indicator 99 & - & CED, WD, GWP, AC, POF & [65] \\
\hline Italy & $\begin{array}{l}1 \text { glass bottle } \\
\text { of } 0.75 \mathrm{~L} \text { of } \\
\text { EVOO }\end{array}$ & $X$ & $X$ & & & $\begin{array}{l}\text { Different stages of } \\
\text { olive oil chain }\end{array}$ & ILCD Midpoint 2011 & - & $\begin{array}{l}\text { GWP, OD, HT, PMF, IR, } \\
\text { POF, AC, TE, FE, ME, FEC, } \\
\text { LU, WRD, MFRD }\end{array}$ & [66] \\
\hline Spain & $\begin{array}{c}1 \mathrm{~kg} \text { of } \\
\text { unpacked } \\
\text { VOOs }\end{array}$ & $x$ & $X$ & & & $\begin{array}{l}\text { Traditional and } \\
\text { intensive VOO } \\
\text { production } \\
\end{array}$ & $\begin{array}{l}\text { ILCD } \\
2011 \text { Midpoint }\end{array}$ & SimaPro 9.0 & $\begin{array}{l}\text { GWP, OD, HT, PMF, IR, } \\
\text { POF, AC, TE, FE, ME, FEC, } \\
\text { LU, WRD, MRD }\end{array}$ & [67] \\
\hline
\end{tabular}

$\mathrm{AC}=$ acidification, $\mathrm{AD}=$ abiotic depletion, $\mathrm{AEC}=$ aquatic ecotoxicity, $\mathrm{ALO}=$ agricultural land occupation, $\mathrm{BC}=$ biomass consumption, $\mathrm{CED}=$ cumulative energy demand, EC = energy consumption, EU = eutrophication, FD = fossil depletion, FE = freshwater eutrophication, FEC = freshwater ecotoxicity, GWP = global warming potential, $\mathrm{HT}=$ human toxicity, $\mathrm{IR}=$ ionizing radiation, $\mathrm{LU}=$ land use, $\mathrm{MD}=$ mineral depletion, $\mathrm{ME}=$ marine eutrophication, MEC = marine ecotoxicity, MFRD = mineral, fossil, renewable depletion, $\mathrm{MRC}=$ mineral resource consumption, $\mathrm{MRD}=$ mineral resource depletion, $\mathrm{NLO}=$ natural land transformation, NRE = non-renewable energy, NREC = non-renewable consumption, OD = ozone depletion, $\mathrm{PMF}=$ particulate matter formation, $\mathrm{POF}=$ photochemical oxidant formation, $\mathrm{RC}=$ resource consumption, $\mathrm{REC}=$ renewable energy consumption, $\mathrm{TA}=$ terrestrial acidification, TE = terrestrial eutrophication, TEC = terrestrial ecotoxicity, ULO = urban land occupation, WD = water depletion, WRD = water resource depletion. 


\section{Conclusions}

The supply chain of olive oil involves many stages, such as farming (including cultivation and harvesting), extraction of oil from olives, packing, and waste treatment steps.

In this regard, the application of LCA is a useful tool to identify the most impacting steps and compare them with sustainable alternatives or implementations.

This review aimed to outline papers within the last decade (2011-2021) involving a "full" LCA study in the olive oil supply chain.

It was pointed out that few studies were found in the literature that highlight the possibility of deepening knowledge of the impact of the olive oil life cycle.

The papers analyzed in this review used direct data collection to perform LCA, and they referred to the Ecoinvent, Agri-footprint, and ELCD databases for secondary data.

The functional units most used were olive ( $1 \mathrm{~kg}$ to $1 \mathrm{ton}$ ) or olive oil ( $1 \mathrm{~L}$ to 1 bottle) amounts. The impact assessment methods most used in the impact assessment were ILCD $(33 \%), \operatorname{ReCiPe}(30 \%)$, and CML (26\%). It was pointed out that a significant proportion of the authors (25\%) did not report the name of the software used. SimaPro was confirmed to be the most used paid software (68\%), and even OpenLCA was shown to be a helpful tool for LCA studies.

The study of the literature shows that the results are very heterogeneous. There are many differences in the methodology applied (software, impact assessment methods, etc.) and the production processes, which do not allow for a simple comparison between the different studies.

However, it can be emphasized that the most impacting stage is farming due to the use of pesticides, fertilizers, water, and fuel for machinery.

Organic systems highlighted lower environmental impacts in almost all the categories studied. The minor impact was due to the absence of synthetic fertilizers and pesticides, affecting the climate change and acidification impact categories.

It was also shown that the functional units defined in the goal and scope definition step had a major influence on the LCA results, as was found for the mechanization of the processes or the use of intensive systems.

Some considerations can then be made concerning experimental design. The place of production certainly influences the final impact, both for the specific climatic conditions and for production regulations. The quality of the final product has the most significant influence on the final result. High quality standards in the extraction process, as well as in the packaging or farming stage, have repercussions for the environmental impacts related to them.

Unquestionably, waste treatment exerts a significant influence on the final result. To date, a process that allows for the best disposal of waste from the oil industry has not yet been found, which is a real problem. However, new approaches are proposed (such as the recovery of bioactive compounds from wastewater, etc.), and they deserve a sustainability evaluation employing LCA.

Another interesting aspect is the $\mathrm{CO}_{2}$ balance that some papers introduced. Considering the absorbed $\mathrm{CO}_{2}$ during the farming stage - thanks to the chlorophyll photosynthesiswould lead to a more in-depth and accurate impact analysis.

Author Contributions: Conceptualization, M.R. and S.C.; methodology, M.R. and S.C.; formal analysis, M.R. and S.C.; writing-original draft preparation, M.R.; writing-review and editing, M.R. and S.C.; supervision, M.R. All authors have read and agreed to the published version of the manuscript.

Funding: This research received no external funding.

Institutional Review Board Statement: Not applicable.

Data Availability Statement: Not applicable.

Conflicts of Interest: The authors declare no conflict of interest. 


\section{References}

1. Vinci, G.; Ruggeri, M.; Rapa, M.; Ruggieri, R. Smart cities in Italy: An intelligent contribution to sustainable development. Int. J. Innov. Technol. Explor. Eng. 2019, 8, 105-110.

2. Campiglia, E.; Gobbi, L.; Marucci, A.; Rapa, M.; Ruggieri, R.; Vinci, G. Hemp Seed Production: Environmental Impacts of Cannabis Sativa L. Agronomic Practices by Life Cycle Assessment (LCA) and Carbon Footprint Methodologies. Sustainability 2020, 12, 6570. [CrossRef]

3. Bai, Z.; Schmidt-Traub, G.; Xu, J.; Liu, L.; Jin, X.; Ma, L. A food system revolution for China in the post-pandemic world. Resour. Environ. Sustain. 2020, 2, 100013. [CrossRef]

4. Tanimonure, V.A.; Naziri, D. Impact of climate adaptation strategies on the net farm revenue of underutilised indigenous vegetables' (UIVs) production in Southwest Nigeria. Resour. Environ. Sustain. 2021, 5, 100029. [CrossRef]

5. Conca, L.; Manta, F.; Morrone, D.; Toma, P. The impact of direct environmental, social, and governance reporting: Empirical evidence in European-listed companies in the agri-food sector. Bus. Strat. Environ. 2021, 30, 1080-1093. [CrossRef]

6. Chandrakumar, C.; McLaren, S.J.; Jayamaha, N.; Ramilan, T. Absolute Sustainability-Based Life Cycle Assessment (ASLCA): A Benchmarking Approach to Operate Agri-food Systems within the $2{ }^{\circ} \mathrm{C}$ Global Carbon Budget. J. Ind. Ecol. $2018,23,906-917$. [CrossRef]

7. Ijassi, W.; Ben Rejeb, H.; Zwolinski, P. Environmental Impact Allocation of Agri-food Co-products. Procedia CIRP 2021, 98 , 252-257. [CrossRef]

8. Morais, T.G.; Teixeira, R.F.M.; Domingos, T. Regionalization of agri-food life cycle assessment: A review of studies in Portugal and recommendations for the future. Int. J. Life Cycle Assess. 2016, 21, 875-884. [CrossRef]

9. Salemdeeb, R.; Saint, R.; Clark, W.; Lenaghan, M.; Pratt, K.; Millar, F. A pragmatic and industry-oriented framework for data quality assessment of environmental footprint tools. Resour. Environ. Sustain. 2021, 3, 100019. [CrossRef]

10. Wang, Y.; Yuan, Z.; Tang, Y. Enhancing food security and environmental sustainability: A critical review of food loss and waste management. Resour. Environ. Sustain. 2021, 4, 100023. [CrossRef]

11. Wang, Y.; Tang, Y.; Li, M.; Yuan, Z. Aeration rate improves the compost quality of food waste and promotes the decomposition of toxic materials in leachate by changing the bacterial community. Bioresour. Technol. 2021, 340, 125716. [CrossRef]

12. Berry, E.M. Sustainable Food Systems and the Mediterranean Diet. Nutrients 2019, 11, 2229. [CrossRef] [PubMed]

13. Azzurra, A.; Massimiliano, A.; Angela, M. Measuring sustainable food consumption: A case study on organic food. Sustain. Prod. Consum. 2019, 17, 95-107. [CrossRef]

14. Pattara, C.; Russo, C.; Antrodicchia, V.; Cichelli, A. Carbon footprint as an instrument for enhancing food quality: Overview of the wine, olive oil and cereals sectors. J. Sci. Food Agric. 2017, 97, 396-410. [CrossRef]

15. Pattara, C.; Salomone, R.; Cichelli, A. Carbon footprint of extra virgin olive oil: A comparative and driver analysis of different production processes in Centre Italy. J. Clean. Prod. 2016, 127, 533-547. [CrossRef]

16. Rinaldi, S.; Barbanera, M.; Lascaro, E. Assessment of carbon footprint and energy performance of the extra virgin olive oil chain in Umbria, Italy. Sci. Total Environ. 2014, 482-483, 71-79. [CrossRef]

17. Bessou, C.; Basset-Mens, C.; Tran, T.; Benoist, A. LCA applied to perennial cropping systems: A review focused on the farm stage. Int. J. Life Cycle Assess. 2013, 18, 340-361. [CrossRef]

18. Vinci, G.; D’Ascenzo, F.; Esposito, A.; Rapa, M.; Rocchi, A.; Ruggieri, R. Sustainability of technological innovation investments: Photovoltaic panels case study. Int. J. Civ. Eng. Technol. 2019, 10, 2301-2307.

19. Vinci, G.; D'Ascenzo, F.; Esposito, A.; Musarra, M.; Rapa, M.; Rocchi, A. A sustainable innovation in the Italian glass production: LCA and Eco-Care matrix evaluation. J. Clean. Prod. 2019, 223, 587-595. [CrossRef]

20. Rapa, M.; Vinci, G.; Gobbi, L. Life cycle assessment of photovoltaic implementation: An italian case study. Int. J. Civ. Eng. Technol. 2019, 10, 1657-1663.

21. Vinci, G.; Rapa, M. Hydroponic cultivation: Life cycle assessment of substrate choice. Br. Food J. 2019, 121, 1801-1812. [CrossRef]

22. Rajaeifar, M.A.; Akram, A.; Ghobadian, B.; Rafiee, S.; Heidari, M.D. Energy-economic life cycle assessment (LCA) and greenhouse gas emissions analysis of olive oil production in Iran. Energy 2014, 66, 139-149. [CrossRef]

23. Avraamides, M.; Fatta, D. Resource consumption and emissions from olive oil production: A life cycle inventory case study in Cyprus. J. Clean. Prod. 2008, 16, 809-821. [CrossRef]

24. Pellegrini, G.; Ingrao, C.; Camposeo, S.; Tricase, C.; Contò, F.; Huisingh, D. Application of water footprint to olive growing systems in the Apulia region: A comparative assessment. J. Clean. Prod. 2016, 112, 2407-2418. [CrossRef]

25. Proietti, S.; Sdringola, P.; Regni, L.; Evangelisti, N.; Brunori, A.; Ilarioni, L.; Nasini, L.; Proietti, P. Extra Virgin Olive oil as carbon negative product: Experimental analysis and validation of results. J. Clean. Prod. 2017, 166, 550-562. [CrossRef]

26. Cappelletti, G.M.; Grilli, L.; Nicoletti, G.M.; Russo, C. Innovations in the olive oil sector: A fuzzy multicriteria approach. J. Clean. Prod. 2017, 159, 95-105. [CrossRef]

27. Bernardi, B.; Falcone, G.; Stillitano, T.; Benalia, S.; Strano, A.; Bacenetti, J.; De Luca, A.I. Harvesting system sustainability in Mediterranean olive cultivation. Sci. Total Environ. 2018, 625, 1446-1458. [CrossRef]

28. Batuecas, E.; Tommasi, T.; Battista, F.; Negro, V.; Sonetti, G.; Viotti, P.; Fino, D.; Mancini, G. Life Cycle Assessment of waste disposal from olive oil production: Anaerobic digestion and conventional disposal on soil. J. Environ. Manag. 2019, 237, 94-102. [CrossRef] [PubMed] 
29. Espadas-Aldana, G.; Vialle, C.; Belaud, J.-P.; Vaca-Garcia, C.; Sablayrolles, C. Analysis and trends for Life Cycle Assessment of olive oil production. Sustain. Prod. Consum. 2019, 19, 216-230. [CrossRef]

30. Banias, G.; Achillas, C.; Vlachokostas, C.; Moussiopoulos, N.; Stefanou, M. Environmental impacts in the life cycle of olive oil: A literature review. J. Sci. Food Agric. 2017, 97, 1686-1697. [CrossRef] [PubMed]

31. Navarro, A.; Puig, R.; Martí, E.; Bala, A.; Fullana-i-Palmer, P. Tackling the Relevance of Packaging in Life Cycle Assessment of Virgin Olive Oil and the Environmental Consequences of Regulation. Environ. Manag. 2018, 62, 277-294. [CrossRef]

32. Cappelletti, G.M.; Ioppolo, G.; Nicoletti, G.M.; Russo, C. Energy Requirement of Extra Virgin Olive Oil Production. Sustainability 2014, 6, 4966-4974. [CrossRef]

33. Sales, H.; Nunes, J.; Patto, M.C.V. Achievements and Challenges towards a Sustainable Conservation and Use of 'Galega vulgar' Olea europaea Variety. Agronomy 2020, 10, 1467. [CrossRef]

34. Malandrino, O.; Rapa, M.; Ruggieri, R.; Vinci, G. Is the electric mobility really green? A Life Cycle Thinking approach. In Proceedings of the 2020 IEEE International Conference on Environment and Electrical Engineering and 2020 IEEE Industrial and Commercial Power Systems Europe, EEEIC/I and CPS Europe 2020, Madrid, Spain, 9-12 June 2020.

35. Brahmi, F.; Flamini, G.; Mechri, B.; Hammami, M. Effect of the Growing Area and Cultivar on Phenolic Content and Volatiles Compounds of Related Products of Selected Tunisian Olive Varieties. In Virgin Olive Oil: Production, Composition, Uses and Benefits for Man; Nova Science Pub Inc.: New York, NY, USA, 2014; ISBN 9781631176623.

36. Boskou, D. Olive oil: Properties and processing for use in food. In Specialty Oils and Fats in Food and Nutrition: Properties, Processing and Applications; Woodhead Publishing: Sawston, UK, 2015; ISBN 9781782423973.

37. Godoy-Caballero, M.d.P.; Acedo-Valenzuela, M.I.; Galeano-Díaz, T.; Goicoechea, H.; Culzoni, M.J. Olive Oil: Production and Nutritional Properties. In Virgin Olive Oil: Production, Composition, Uses and Benefits for Man; Nova Science Pub Inc.: New York, NY, USA, 2014; ISBN 9781631176623.

38. Chih, H.J. Olive Oil: Production, Bioactive Properties and Public Health. In Virgin Olive Oil: Production, Composition, Uses and Benefits for Man; Nova Science Pub Inc.: New York, NY, USA, 2014; ISBN 9781631176623.

39. Rojas-Sola, J.I.; Castro-García, M. Analysis Through Graphical Knowledge of Historical Olive Oil Production Obtained from Mechanical Procedures: Application to the Invention Privileges and Patents from the Historical Archive of the Spanish Office of Patents and Trademarks. In Virgin Olive Oil: Production, Composition, Uses and Benefits for Man; Nova Science Pub Inc.: New York, NY, USA, 2014; ISBN 9781631176623.

40. Gómez-Caravaca, A.M.; Verardo, V.; Bendini, A.; Gallina Toschi, T. From Wastes to Added Value By-Products: An Overview on Chemical Composition and Healthy Properties of Bioactive Compounds of Olive Oil Chain By-Products. In Virgin Olive Oil: Production, Composition, Uses and Benefits for Man; Nova Science Pub Inc.: New York, NY, USA, 2014; ISBN 9781631176623.

41. Wernet, G.; Bauer, C.; Steubing, B.; Reinhard, J.; Moreno-Ruiz, E.; Weidema, B. The ecoinvent database version 3 (part I): Overview and methodology. Int. J. Life Cycle Assess. 2016, 21, 1218-1230. [CrossRef]

42. Durlinger, B.; Tyszler, M.; Scholten, J.; Broekema, R.; Blonk, H. Agri-Footprint; A Life Cycle Inventory database covering food and feed production and processing. In Proceedings of the 9th International Conference on Life Cycle Assessment in the Agri-Food Sector (LCA Food 2014), San Francisco, CA, USA, 8-10 October 2014.

43. Wolf, M.; Pennington, D.; Pant, R.; Chomkhamsri, K.; Pretato, U.; Commission, E. European Reference Life Cycle Database (ELCD). Database 2008, 1-30.

44. Romero-Gámez, M.; Castro-Rodriguez, J.; Suarez-Rey, E. Optimization of olive growing practices in Spain from a life cycle assessment perspective. J. Clean. Prod. 2017, 149, 25-37. [CrossRef]

45. Ben Abdallah, S.; Elfkih, S.; Suárez-Rey, E.M.; Parra-López, C.; Romero-Gámez, M. Evaluation of the environmental sustainability in the olive growing systems in Tunisia. J. Clean. Prod. 2021, 282, 124526. [CrossRef]

46. Bernardi, B.; Falcone, G.; Stillitano, T.; Benalia, S.; Bacenetti, J.; De Luca, A.I. Harvesting system sustainability in Mediterranean olive cultivation: Other principal cultivar. Sci. Total Environ. 2021, 766, 142508. [CrossRef] [PubMed]

47. De Gennaro, B.; Notarnicola, B.; Roselli, L.; Tassielli, G. Innovative olive-growing models: An environmental and economic assessment. J. Clean. Prod. 2012, 28, 70-80. [CrossRef]

48. De Luca, A.I.; Stillitano, T.; Falcone, G.; Squeo, G.; Caponio, F.; Strano, A.; Gulisano, G. Economic and environmental assessment of extra virgin olive oil processing innovations. Chem. Eng. Trans. 2018, 67, 133-138. [CrossRef]

49. Stillitano, T.; Falcone, G.; De Luca, A.I.; Piga, A.; Conte, P.; Strano, A.; Gulisano, G. Innovative technologies in evo oil extraction: An economic and environmental impact analysis. Riv. Ital. delle Sostanze Grasse 2019, 96, 223-230.

50. Accorsi, R.; Versari, L.; Manzini, R. Glass vs. plastic: Life cycle assessment of extra-virgin olive oil bottles across global supply chains. Sustainability 2015, 7, 2818-2840. [CrossRef]

51. Giovenzana, V.; Casson, A.; Beghi, R.; Tugnolo, A.; Grassi, S.; Alamprese, C.; Casiraghi, E.; Farris, S.; Fiorindo, I.; Guidetti, R. Environmental benefits: Traditional vs innovative packaging for olive oil. Chem. Eng. Trans. 2019, 75, 193-198. [CrossRef]

52. Rapa, M.; Vinci, G.; Ciano, S.; Cerra, S.; Fratoddi, I. Gold nanoparticles-based extraction of phenolic compounds from olive mill wastewater: A rapid and sustainable method. AIP Conf. Proc. 2020, 2257, 020010. [CrossRef]

53. Parascanu, M.M.; Puig Gamero, M.; Sánchez, P.; Soreanu, G.; Valverde, J.L.; Sanchez-Silva, L. Life cycle assessment of olive pomace valorisation through pyrolysis. Renew. Energy 2018, 122, 589-601. [CrossRef]

54. De Marco, I.; Riemma, S.; Iannone, R. Global Warming Potential analysis of olive pomace processing. Chem. Eng. Trans. 2017, 57, 601-606. [CrossRef] 
55. Puig-Gamero, M.; Parascanu, M.M.; Sánchez, P.; Sanchez-Silva, L. Olive pomace versus natural gas for methanol production: A life cycle assessment. Environ. Sci. Pollut. Res. 2021, 28, 30335-30350. [CrossRef]

56. Yay, A.S.E.; Birinci, B.; Açıkalın, S.; Yay, K. Hydrothermal carbonization of olive pomace and determining the environmental impacts of post-process products. J. Clean. Prod. 2021, 315, 128087. [CrossRef]

57. Hjaila, K.; Baccar, R.; Sarra, M.; Gasol, C.; Blánquez, P. Environmental impact associated with activated carbon preparation from olive-waste cake via life cycle assessment. J. Environ. Manag. 2013, 130, 242-247. [CrossRef]

58. El Hanandeh, A. Energy recovery alternatives for the sustainable management of olive oil industry waste in Australia: Life cycle assessment. J. Clean. Prod. 2015, 91, 78-88. [CrossRef]

59. Espadas-Aldana, G.; Guaygua-Amaguaña, P.; Vialle, C.; Belaud, J.-P.; Evon, P.; Sablayrolles, C. Life Cycle Assessment of Olive Pomace as a Reinforcement in Polypropylene and Polyethylene Biocomposite Materials: A New Perspective for the Valorization of This Agricultural By-Product. Coatings 2021, 11, 525. [CrossRef]

60. López-García, A.; Cotes-Palomino, T.; Uceda-Rodríguez, M.; Moreno-Maroto, J.; Cobo-Ceacero, C.; Andreola, N.; Martínez-García, C. Application of Life Cycle Assessment in the Environmental Study of Sustainable Ceramic Bricks Made with 'alperujo' (Olive Pomace). Appl. Sci. 2021, 11, 2278. [CrossRef]

61. Iraldo, F.; Testa, F.; Bartolozzi, I. An application of Life Cycle Assessment (LCA) as a green marketing tool for agricultural products: The case of extra-virgin olive oil in Val di Cornia, Italy. J. Environ. Plan. Manag. 2013, 57, 78-103. [CrossRef]

62. Salomone, R.; Ioppolo, G. Environmental impacts of olive oil production: A Life Cycle Assessment case study in the province of Messina (Sicily). J. Clean. Prod. 2012, 28, 88-100. [CrossRef]

63. El Hanandeh, A.; Gharaibeh, M.A. Environmental efficiency of olive oil production by small and micro-scale farmers in northern Jordan: Life cycle assessment. Agric. Syst. 2016, 148, 169-177. [CrossRef]

64. Fernández-Lobato, L.; López-Sánchez, Y.; Blejman, G.; Jurado, F.; Moyano-Fuentes, J.; Vera, D. Life cycle assessment of the Spanish virgin olive oil production: A case study for Andalusian region. J. Clean. Prod. 2021, 290, 125677. [CrossRef]

65. Tsarouhas, P.; Achillas, C.; Aidonis, D.; Folinas, D.; Maslis, V. Life Cycle Assessment of olive oil production in Greece. J. Clean. Prod. 2015, 93, 75-83. [CrossRef]

66. Guarino, F.; Falcone, G.; Stillitano, T.; De Luca, A.I.; Gulisano, G.; Mistretta, M.; Strano, A. Life cycle assessment of olive oil: A case study in southern Italy. J. Environ. Manag. 2019, 238, 396-407. [CrossRef]

67. Fernández-Lobato, L.; García-Ruiz, R.; Jurado, F.; Vera, D. Life cycle assessment, C footprint and carbon balance of virgin olive oils production from traditional and intensive olive groves in southern Spain. J. Environ. Manag. 2021, 293, 112951. [CrossRef]

68. Arzoumanidis, I.; Salomone, R.; Petti, L.; Mondello, G.; Raggi, A. Is there a simplified LCA tool suitable for the agri-food industry? An assessment of selected tools. J. Clean. Prod. 2017, 149, 406-425. [CrossRef] 